\title{
THE FUTURE OF PRICE: Communicative Infrastructures and the Financialization of Indian Tea
}

\author{
SARAH BESKY \\ Brown University \\ (D) http:// orcid.org/0000-0003-2353-0074
}

Surrounded by sprawling gardens and statues of horse-mounted British dignitaries, Kolkata's Victoria Memorial is perhaps the most iconic relic of colonial power in a city filled with them. Today, in what once was the center of the Raj, the Kolkata police arrange diesel-stained metal road barricades to create a buffer between the capaciousness of Victoria Memorial's grounds and the congestion of Kolkata's streets - from the honks of motorbikes and Ambassador taxis to the smells of horse-drawn silver phaetons and fresh puchka. Each of these barricades is adorned with hand-painted advertisements. These advertisements, for everything from snacks to steel, are usually unmemorable, but while I was doing fieldwork on Kolkata's tea trade in 2008 and 2009, one stood out. The lettering read "teauction.com," and it was embossed with a little teapot.

Teauction.com named an attempt to change the way Indian tea was traded. Tea - unlike other major commodity crops, including coffee, cotton, and sugaris still bought and sold in open-outcry auctions, held in former imperial centers from Kolkata to Colombo to Mombasa. ${ }^{1}$ In 2002, Indian state and industry reformers launched teauction.com in hopes that its online platform would take the place of outcry auctions. For reformers, online auctioning was a first step toward the financialization of the tea market. Supporters of teauction.com promised that with the implementation of digital technologies, trade would soon revolve around the buying and selling of futures contracts, not individual lots of tea. 


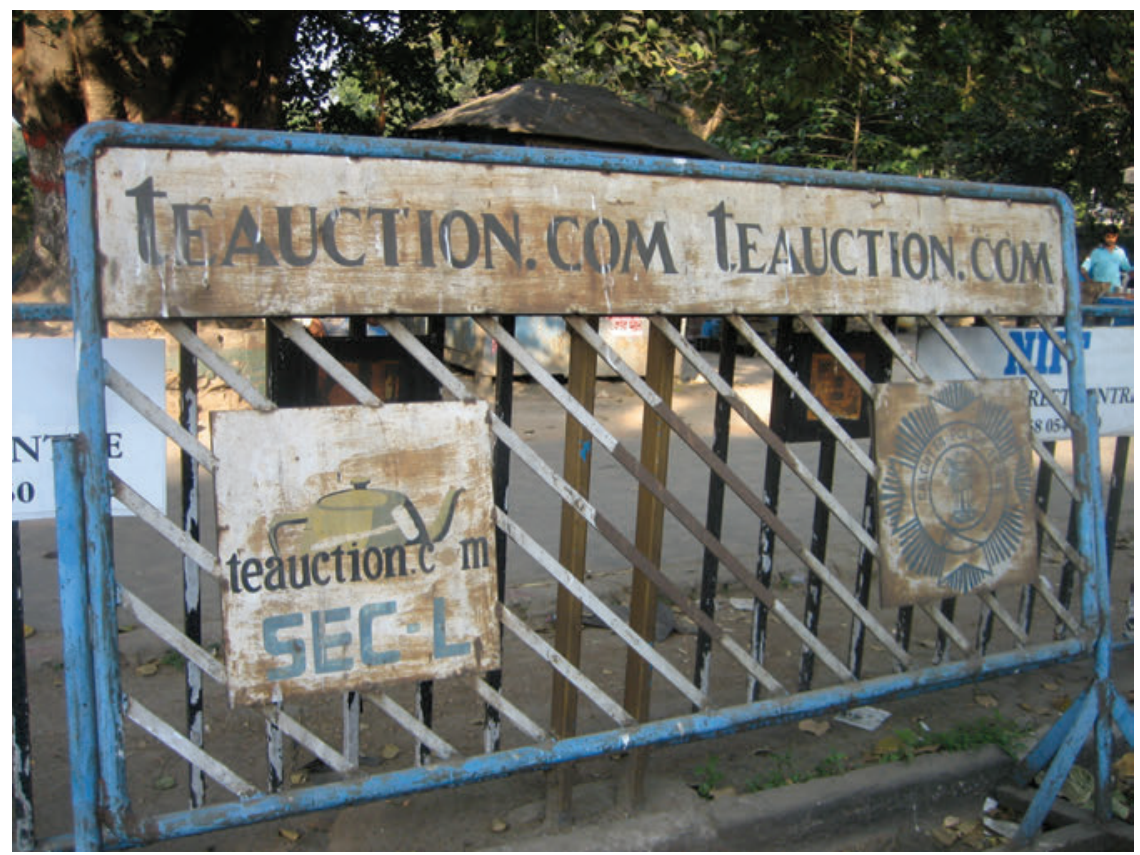

Figure 1. Road barricade outside of Victoria Memorial, December 2008. Photo by Sarah Besky.

But the shift to digital auctioning, which began with the launch of teauction.com, has yet to spark the transformative break that industry reformers envisioned. Among my field materials, the photo of the teauction.com advertisement on the Kolkata police barricade sits amid a slew of unfulfilled pronouncements from the Indian and international press about the imminent revolution that finance capital would bring to the market for the world's most popular beverage. At the time of this writing, tea sales have not only not been fully digitized, but the Indian tea trade has resisted all associated attempts at financialization, including the creation of a futures market. The global financial system is more powerful than many nation-states and individual corporations (LiPuma and Lee 2004, 32), but that so prominent a commodity as tea has yet to be financialized provides a unique opportunity to examine the how of financialization - the governmental and technical steps that precede futures and other kinds of derivatives trades.

In this essay, I describe how, in 2009, tea brokers in Kolkata experienced a renewed effort by the Tea Board of India, the government regulator of the tea trade, to convert auctioning from a face-to-face outcry process to a face-tocomputer digital one. The goal was to break the control that brokers had over the trade. Outcry brokers - a small group of well-educated middle-class men- 
embodied a hidden authority that seemed at odds with free and open trade. Anthropologists have documented the cultural and economic volatility of financial markets, tracing the sociopolitical impact of digital trading technologies and new kinds of speculation (D’Avella 2014; Ho 2009; Miyazaki 2013; Zaloom 2006). Financialization does not take the same form everywhere; sometimes, it does not really take form at all. As Donald MacKenzie (2006, 13-15) has argued, following William Cronon (1992) and Michel Callon (1998), the futures market is a key site for seeing how theories about the disentanglement of commodities - a stripping away of the particularities of quality based on production - get put into action. Futures markets rely on a standardized notion of price and of the things (e.g., grain, cotton, or coffee) being priced. This disentangling brings commodities into a rational trading infrastructure. The story of Indian tea's resistance to financialization shows how such standardization requires not just a disentangling of commodities at the level of productive infrastructure but also a reworking of the communicative infrastructure of trading itself.

I am drawing here on Julia Elyachar's (2010, 452) notion of a "social infrastructure of communicative channels.” Elyachar describes women's everyday behind-the-scenes communication and movement through Cairo as constituting an infrastructure that is as important to economic life as roads and bridges. Similarly, the outcry auction and its attendant tasting and valuation practices constitute a communicative infrastructure that has proven central to the circulation of Indian tea for more than 150 years, if also largely hidden from public view. It is this infrastructure that Indian tea industry reformers seek to reconfigure, in a process similar to Caitlin Zaloom's (2006) account of how digital trading in the Chicago and London financial spheres was introduced to rationalize pit trading, with its hand gestures and aggressive hypermasculine posturing.

The shift from outcry to digital trading I describe here, however, is also distinct from that identified by Zaloom. While Zaloom's brokers contemplated a move from outcry to digital trading in already-financialized commodities, the Indian tea brokers with whom I worked were trading a commodity that was in the process of being converted, through a combination of applied economic theory and state intervention, into a commodity open to speculation. As I show below, in Kolkata, financialization depended on an understanding of tea as more narrowly commensurable than brokers had previously allowed. In Indian tea, the digital transition was meant to foment commensurability by reforming the ways traders produced numbers - how they, in Jane Guyer's (2009) terms, “composed prices." It is this change in price composition - a change that occurs in histori- 
cally, technologically, and politically situated ways - that brings commodities into global financial markets.

After the failure of teauction.com, the Tea Board of India hired a consulting firm to identify ways to ensure the long-term viability of the industry. In the firm's own words, the role of an auction was to effect "natural price discovery" (A. F. Ferguson 2004). In what follows, I describe the Tea Board's rocky attempts to implement the consultants' recommendations.

In Kolkata's outcry auctions, knowledge about tea is held and cultivated in a guild-like community of brokers. The brokers who buy and sell tea are nearly all middle-class men, trained through years of apprenticeship and registered with the Calcutta Tea Traders Association (CTTA). They compose price through what Julia Elyachar (2012) has elsewhere described as a cultivated corpus of "tacit knowledge," ranging from tasting to soil chemistry to a specialized vocabulary for describing tea's flavor, geographical origin, and method of production. In the space of the outcry auction, brokers collectively refine this knowledge through shared cups and clipped discussion. Brokers compose price through what I call price stories, narratives about value that are tuned to specific lots of tea.

By the time my fieldwork began, the fate of this colonially rooted system, like that of other more recognizable monuments to British imperialism in India, such as the Victoria Memorial, had become a topic of heated debate. The persistence of the outcry auction had come to represent the Tea Board of India's failure to use the bureaucracy to maximize economic growth. The cloistered interpretations of the tastes and provenances of teas by a relatively small group of welleducated Indian men were difficult to regulate. For Tea Board officials, there was no logical explanation for why some lots were aggressively fought over while others needed an auctioneer's coaxing. Brokers' carefully crafted, guildlike pricing methods - enmeshed in what Elyachar (2012, 85) calls "secrets of the trade"seemed anathema to free markets, much less complex financial systems. Their friendly personal relations indicated an entrenched, even corrupt elite capture of a potentially lucrative global market. While secrets of the trade are classically associated with a bygone era of (precapitalist) guild-based knowledge communities, in India's tea auctions (as in those of East Africa and Sri Lanka, which have also resisted financialization), these secrets emerged within the colonial system of capital accumulation.

In place of stories, the digital auctioning platform set up a method for composing price through scenarios. Scenarios limit the kinds of information available and the kinds of communicative exchanges that can take place. In price 
scenarios, brokers would deploy not trade secrets but the kind of tacit knowledge that, according to Elyachar $(2012,86)$, liberal market theorists imagine as conducive to quality price discovery (see also Zaloom 2003, 2006). This form of tacit knowledge is held individually, rather than collectively, and applied not to specific lots of tea, but to broad categories that encompass many presumably commensurable lots. This change in the relationship of tacit knowledge to price was a key step to financialization. Reformers wanted to reassert public control over the auction - still a vestige of colonial infrastructure. Like Victoria Memorial's manicured gardens, the outcry auction's esoteric language and embodied practice had to become a public good. Ironically, reformers asserted this public control by embracing a free-market logic based on behavioral economics: a logic that saw a rationalized price system as the key to translating unspoken, embodied knowledge into fungible information (Elyachar 2012, 86).

\section{PRICE AND THE OBSTACLES TO FINANCIALIZATION}

Beginning in 2008, I observed the digital transition and interviewed actors on all sides - Tea Board bureaucrats, corporate players, multigenerational small tea businesses, and brokers. The Tea Board's claims that it was creating transparency in price composition were met with brokers' counterclaims that the digital platform itself constituted a corrupting force. These arguments reflect wider anxieties about the shift to market-oriented democracy in South Asia. As William Mazzarella (2006, 476) notes, digital technologies in India deployed in the project of stemming corruption are often productive of their own kinds of opacities (cf. Gupta 1995; Hull 2012). Putting the anthropology of markets and finance into conversation with an analysis of how other colonial forms of enumeration and value stubbornly persist in the present, I underscore a struggle to come to terms not just with the legacy of colonial commodities but with the embeddedness of the colonial order in sensory regimes of gender, race, and taste (Stoler 1995, 2002).

That the outcry auction has been a major target for tea industry reform in India may appear somewhat surprising. Explanations for tea's resistance to financialization can easily be found in its continued entanglement in a colonial infrastructure of production (see MacKenzie 2006, 13). The vast majority of Indian tea is still grown on plantations, from Kangra to Kerala to Assam. As in East Africa and Sri Lanka, tea exported from or sold within India is not a raw commodity (like, for instance, green unroasted coffee beans). Instead, it is a fully finished product. Unprocessed leaves are highly perishable. Each Indian tea plan- 
tation contains a factory in which workers wither, ferment, roll, dry, and sort teas to give them particular flavors. A multiplicity of factory finishing methods yields a multiplicity of teas, broken down by geographical location, grade, and season. Further complicating this process is the fact that tea is not an annual or seasonal harvest. Tea is plucked and processed every day for ten or more months of the year. This variability leads to volatility, both in price and taste. Volatility can of course be desirable in finance, but the sheer variety of different styles and grades of tea has created a sense of confusion among would-be speculators.

The Tea Board of India's interest in the auction can be explained in part as an effort to save it. Increasingly, Indian tea is sold outside the auction system. To date, direct trading or private sales have encompassed mostly specialty, fair-trade, or single-origin teas (Besky 2014a). ${ }^{3}$ Auctions remain the trading point for most mass-market tea. In auctions, tea is subjected to a complex method of valuation, controlled by professional brokers. The anxieties of Tea Board officials about the potential of this valuation process to hinder market competition can be linked to a key aspect of trade liberalization in India, namely, the tendency of the state to take an active role in the country's move into a global speculative economy (see Sunder Rajan 2005, 25). The Tea Board, in other words, wanted to keep a hand in the composition of price. To do so, it needed to intervene in the auction: to establish that this "time-tested system" still had "inherent advantages" over private sales, including efficiency, timeliness of payment, regularity of supply, and centrality of organization (A.F. Ferguson 2004, 4.4.05). The consultants were explicitly tasked with establishing ways to get more tea into auctions.

Much of the ethnographic material in this essay comes from India's oldest and largest auction center, Nilhat House, located a couple of miles north of the Victoria Memorial, in the heart of old Kolkata. At Nilhat House, a material plantation infrastructure converges with a communicative infrastructure of trading (Elyachar 2010). For more than 150 years, most tea grown on plantations in northeast India has been sold in weekly outcry auctions in Kolkata. Three weeks in advance of each auction, tea plantation companies contract representatives of brokerage firms registered with the CTTA to taste and evaluate their individual lots of tea. After tasting and evaluating the lots, these seller-brokers distribute a list of valuation prices, along with tea samples, to buyer-brokers from firms also registered with the CTTA. ${ }^{4}$ Buyer-brokers do their own tasting and evaluation to determine whether they want to bid on behalf of retail companies across the world and at what price. Since its inception, the auction at Nilhat House has been 
a closed performance, regulated at first only by the CTTA, and after Indian independence in 1947 by the CTTA and the Tea Board of India.

The Tea Board and its consultants determined that the auction was creating a barrier to financialization: that outcry trading was producing unnatural prices. According to Jane Guyer (2009, 203), the observation-rooted in Karl Marx's (1976) notion of the commodity fetish and Karl Polanyi's (2001) subsequent analysis of "fictitious commodities" - that price is not a "singular amount," but a "composite," a "fiction" resulting from acts of "creation, addition, and subtraction," is now widely accepted by consumers and traders. The task of anthropological analysis, then, is to decompose price: to reveal what prices keep "hidden in plain sight" (Guyer 2009, 205). Classically, these hidden terms, following a Polanyian analysis, would include land, labor, capital, and the state - the trappings of the tea production infrastructure that might easily be foregrounded as the main hindrance to tea's financialization.

In Indian tea, these hidden terms also include the communicative infrastructure of brokerage. As an ideology, price "circumvents . . . moral and political commentary" about these elements of composition, naturalizing their arrangements (Guyer 2009, 204). Proponents of both the old outcry system and the new digital system freely acknowledged that prices were compositions. They differed in their view of how the human capacity to taste and judge - to act on nonquantitative knowledge-should go into those compositions. While outcry brokers mobilized a set of collectively held trade secrets, proponents of digital auctioning favored a cultivation of individually held knowledge. What Michael Polanyi (2009) called "tacit knowledge" needed to move from the collective, storied world of outcry auctioning to the atomized, scenario-based world of digital trading (Elyachar 2012). As Elyachar (2012, 80) explains, liberal market orthodoxy presumes that "quality prices" — a prerequisite for the elaboration of free markets as well as complex financial transactions - only emerge insofar as private individuals, not collectives, wield tacit knowledge. The ideal trading sphere is not a place to cultivate and share ideas about value but act on already-formed ideas.

In her description of the shift from pit to digital trading, Zaloom (2006, 136) notes that the market became not something a trader worked with but something he reacted to (see also Preda 2006). The Indian brokers with whom I worked rarely spoke directly about the market. They spoke about tea brokerage as a trade: a cultivated craft that deserved to be updated, not abolished. While rationalization and efficiency were certainly on the minds of Indian reformers, outcry tea brokers saw themselves working not so much with a generalized market 
as with specified kinds of tea. The financialization of tea entailed work by state and industry actors to reconcile the sensory legacies of colonialism with the demands of a fast-moving global financial system.

\section{OUTCRY AUCTIONING AND PRICE STORIES}

Mr. Dey, a seller-broker with thirty years of experience, swoops into the auction room, flipping his tie over his shoulder and draping a brown-speckled white apron around his neck. Working his way down a line of cups, he first lifts a saucer filled with steeped tea to his face, burying his nose in the damp aromatic leaves to breathe in the delicate essences. He slams the saucer down, reaches for the cup filled with lukewarm tea, takes three aerated sips-slurp, slurp, slurpand spits the tea in a thin, arching stream out into a dented aluminum bucket. He then turns to his assistant. Drawing from a controlled list of English adjectives that date back to the formation of the auction system in London in the seventeenth century (e.g., "cheesy," “wiry," "biscuity," "knobbly"), he describes the tea's qualities. In addition to this specialized vocabulary, he translates the sensation of that tea - the taste, touch, and smell — as well as his recollections about the color, aroma, and texture of teas that have come up for auction before, comparing this week's lot to last week's, grade by grade, plantation by plantation, to reach a singular number: a valuation price. The assistant follows him, pushing a large easel on which he records these qualitative and quantitative evaluations. Mr. Dey kicks his spit bucket down the line and repeats the procedure with the next cup.

Mr. Dey tells me that tea is unlike coffee or wine, which are annual vintages. In tea, vintages do not correspond to years. Instead, each plantation, or often section of a plantation, on a given day, constitutes a kind of vintage. Each tea, from day to day and season to season, might be fired at different temperatures or fermented for variable amounts of time. This variability ensures that each lot of tea, each week, tastes differently. As a seller-broker, Mr. Dey's job is to narrate this variability to make different lots of tea commensurable with one another through the metric of valuation price. University-educated and a member of several social and sporting clubs, Mr. Dey is a connoisseur of tea as well as of Scotch whisky (he prefers Laphroaig). Company profiles of tea brokers tend to include brokers' interests in cricket, football, and badminton, as well as theater and travel. While some younger brokers avoid alcohol, cigarettes, garlic, and onions for fear of damaging their palettes, Mr. Dey remains a committed gourmand. He has no doubt about his abilities. 
A broker's work is ongoing. Tastes and valuation prices fluctuate dramatically throughout the year because of what people in the tea business refer to as "flushes," or seasons: first flush (mid-March to mid-April), second flush (mid-April to May), monsoon flush (June to August), and autumnal flush (September to November). There are several grades of leaf tea, all yielding different prices, from the highest grade, SFTGFOP (Super Fine Tippy Golden Flowery Orange Pekoe), and descending to FTGFOP (Fine Tippy Golden Flowery Orange Pekoe), TGFOP (Tippy Golden Flowery Orange Pekoe), GFOP (Golden Flowery Orange Pekoe), FOP (Flowery Orange Pekoe), to OP (Orange Pekoe), BOP (Broken Orange Pekoe), and "fannings" (tea typically found in tea bags and in many cases swept up from the factory floor). Further complicating the price of tea are two production processes. There is leaf-grade, or "orthodox" tea, to which these categories apply, and CTC, or "cut-tear-curl" tea, which is rolled into little balls and sold mostly within India and the Middle East (and graded using a set of terms different than those applied to orthodox tea).

After tasting and valuing the long line of teas, Mr. Dey goes downstairs to the auction room. There, lot by lot, Mr. Dey — now as auctioneer-attempts to fetch something close to the valuation price he set upstairs, a number that he sees as a "natural" reflection of quality and desirability. He sits at the front of what resembles a small university lecture hall, before dozens of buyer-brokers who bid by crying out offers. The valuation price is just one of several numerical devices brokers use to distill the qualities of tea. In addition to the circulars outlining that week's valuation prices, auction catalogs sent out by each brokerage firm connote the grade, age, warehouse location, and number of packages of each lot. The numbers in this thick paper booklet structure the interactions between sellerbrokers like Mr. Dey and the buyer-brokers who represent retailers. The paper catalog organizes tea-producing landscapes distant from Kolkata into an order that corresponds to those of grade and flavor.

One by one, Mr. Dey brings up lots for bidding. The sale of two lots of tea sounds something like this. He calls out: "Let's move on to the clonal tip, lot 24."

A call comes from the crowd: "800."

“No, I need 1200,” Mr. Dey replies.

“1100."

"Fine. I will start at 1150."

“1150” . . . “1200” . . “1300” . . . 
"No more bids?" The gavel slams.

"Any interest in the China?"5

“650."

"No good."

“7, sir, 7 ..."

"Not on this tea, sir. Let's start the bidding at 8. 800?"

In the front, a buyer nods. Then another raises his pen. Nods again. Pen. The nodding man stares and then subtly shakes his head. The gavel slams.

The fact that British merchants devised this entire auctioning and valuation system (first in London in the seventeenth century and, later, in Kolkata in 1861) is well known and even celebrated. In 2012, a journalist profiling the 150th anniversary of J. Thomas and Company-the largest brokerage firm in Kolkata and the company that managed the first tea auctions held in India-noted that "recruitment to the profession [of brokerage] is based on sound background, schooling and sportsman-like qualities. The job is generally learnt hands-on" (Priyadershini S. 2012). As J. Thomas's vice-chairman told The Hindu, "tea tasting even today remains the single most reliable method of evaluating a tea." Mr. Dey and his colleagues trade on their ability to taste in both of Pierre Bourdieu's (1984) formulations: to apply a biological sensibility as well as a social capacity to discern flavor. Taste, historically embedded in the trading system of Nilhat House, constitutes an obstacle that the financial system has trouble surmounting. Brokers understand taste, like price, as a compositional, transactional practice that is integrated with histories of materiality as well as ideology (Atkin 2010; Janeja 2010). The article in The Hindu refers to tea auctioning as "the gentleman's trade," replete with "the romance of colonial hangover" (Priyadershini S. 2012). The storied price composition of outcry auctioning requires that Indian brokers perform British taste (that they both belong to the right clubs and can translate sensory experience into the right vocabulary and with the right panache), but also that they cooperate - that they work with tea - to see that as many lots as possible find a buyer.

Brokers on both sides of these transactions are motivated to see them come to a satisfying end. Buyer-brokers and seller-brokers collect fees and commissions for completed sales, but there are other motivations. Despite the vagaries of weather, season, and provenance, companies demand a consistent taste in the tea blends they distribute. A tea bag of Tetley always has to taste like the last bag of Tetley you had. To produce consistent blends, buyer-brokers must find teas with 
certain qualities. Most mass-marketed teas are blended in this way. A given bag of Tetley has different kinds of tea in it. If you were to take two bags of Tetley, the teas that go into it could be from completely different regions and completely different seasons, yet they taste the same. The seemingly abstract numbers in the auction catalog present buyer-brokers trained to read them with the ability to tell the stories of particular teas, to link the differential regime of taste with the abstract regime of price.

Numbers and stories distill social life into order, making things and concepts commensurable and comparable, and they allow people to make normative judgments. By giving tea a story - a chronicity - brokers come to care about each tea's ultimate fate. Chronicity, as Kirin Narayan (1989, 243) has argued, "gives narrative an impression of lifelikeness that can recruit imaginative empathy." Without the stories behind the catalog numbers, seller-brokers and buyer-brokers cannot arrive at a satisfactory (and lucrative) ending: a successful sale. Outcry auctioning is a performance of differentiation whose object is to bring lots of tea from field to cup (Callon 1998). Because of the need for particular tastes, lots are often split between two or sometimes three buyer-brokers. This is achieved by calling out to the current high bidder during the auctioning of that lot to strike an amicable division of the lot, which is broken up into a certain number of packages of variable weights between parties. Lot splitting ensures that each bidder gets at least some of the taste that he wants.

Buyer-brokers and seller-brokers know one another by name. The community of tea trading is a small one, relationships have typically been collegial, and trading decorum has been reserved, unlike the combative and even violent trading pits of Chicago (Zaloom 2006, 111). The gentlemanly repartee of tea brokerage is hidden from those outside Nilhat House. Whereas ideas about the places of production like Darjeeling or Assam have been made increasingly translatable outside the space of the auction, the complex set of descriptive English adjectives, weights, and measures seem opaque to outsiders. Catalog numbers, then, circulate alongside terms like cheesy and biscuity. To those inside Nilhat House these adjectives and numbers reflect the nature of tea, understood by individuals with a shared embodied sensibility and lexicon. They reflect a composition of price in which the sensory qualities of tea-all the things that make it taste-matter. To those outside, they reflect an archaic and colonially rooted system of secrets, of price-fixing and meddling. 


\section{PRICING AND COLONIAL ENUMERATION}

The style of pricing I observed at Nilhat House has roots not only in colonial tea trading but also in broader colonial practices of enumeration. In his work on the colonial census in India, Bernard Cohn $(1996,8)$ examines how the "enumerative modality" of colonial rule created "a particular form of certainty" by putting fluid categories into concrete form. Numbers were used to chart the colonial project of improvement in an array of contexts, from health statistics to literacy rates to agriculture (Arnold 2005; see also Drayton 2000). Census numbers, labor ledgers, and health statistics were effective in charting improvement because they rendered India's melange of cultures, languages, and ethnicities - a melange that was, from a colonial viewpoint, wholly natural-commensurable. A discourse of improvement in colonial enumerating practices had a clear temporal component: bringing the colony out of a backward past and into a suitably modern present. As Arjun Appadurai (1996, 117; emphasis added) suggests: "Numbers gradually became . . . part of the illusion of bureaucratic control and key to a colonial imaginary in which countable abstractions, of people and resources at every imaginable level and for every conceivable purpose, created a sense of a controllable indigenous reality."

Thus, while it is possible to see the colonial project as one of cold ordering, colonial numbers can be more usefully understood as analogous to Jane Guyer's (2009) price compositions, numerals that leave the conditions of their production hidden in plain sight. Like prices, colonial numbers turned a differentiated population into an abstract, improvable object. As Appadurai notes, these attempts at ordering and abstraction, elaborated and re-elaborated in spaces like Nilhat House and its analogues in other imperial ports, became their own kind of unruly profusion. The tea auction catalog is thus one site in which the doubling of abstraction and differentiation, opacity and transparency, becomes apparent (Mazzarella 2006; cf. John 2011).

Numbers continue to be powerful signifiers. Sally Merry (2011) describes global human rights indicators as increasingly popular tools for assessing social justice. These numbers represent everything from economic development to women's rights, and they distill social phenomena into discrete, commensurable forms (see also Espeland and Sauder 2007; Guyer 2010). These distillations have local effects, as Andrea Ballestero (2015) examines in the "calculation grammar" involved in water pricing in Costa Rica, and as Harris Solomon (forthcoming) notes in his critique of popular reliance on a global Body Mass Index for the definition of obesity in India. Such numbers also mask the conditions of their own 
composition. Practices of enumeration reinforce dominant ideas about the capacity of individuals, rather than of collectivities, to manage and mitigate risks, while hiding collective histories of vulnerability. This conversion from collective yet particular forms of vulnerability to individualized abstract risk, calculable in numbers, is a hallmark of so-called market democracy, in which health, environmental, and even political behaviors have been technically and discursively divided into measurable, reflexively felt categories (Elyachar 2005; Paley 2001; Moodie 2010; Beck 1992).

Capitalism, too, depends on numbers to produce a sense of abstract and objective knowledge (Zaloom 2006, 142; Marx 1976; Simmel 1978). In financial markets, numbers attest to the commensurability of both tangible things like corn and intangible things like emissions (MacKenzie 2009; Fourcade 2011; Cronon 1992; Espeland and Stevens 1998). Such markets allow speculation on the future values of commensurable things. Speculation, however, is not a natural outgrowth of commensuration. It must be learned, as I suggest below, through the enactment of scenarios, particularly on digital platforms.

The Tea Board saw digital auctioning as a means of opening and freeing the tea market. Just as colonial bureaucratic enumeration was based on the ideal of rendering a mix of races, ethnicities, languages, and cultures transparent, digital trading technology promised to make the opaque world of valuation transparent. In South Asia, the concepts of transparency and opacity have been threaded into discussions of democracy and corruption (Gupta 1995; Mazzarella 2006). Transparency continues to be an objective of postcolonial bureaucratic governance (Hull 2012). Paradoxically, the Tea Board - a government bureaucracy-used the transparency and free markets promised in the digital auction to reassert regulatory control over the tea industry.

The challenge of financialization - made all the more acute in contexts like India's tea industry — becomes one of how to disentangle economic behavior from (gendered, ethnicized, racialized) affective sensibilities when the very thing being traded (that is, an imperial commodity like Indian tea) is so deeply implicated in the sensory colonialism that paralleled the elaboration of the bureaucratic state. It is the abstractness and numerical legibility of economic categories that makes them seem democratic, yet as Analiese Richard and Daromir Rudnyckyj (2009) have shown, collective affective sensibilities drawn from religious and kinship practices consistently make regional and cultural differentiation central to the making of neoliberal subjects. In Asia, colonial enumeration-from census numbers to ledger books - was entangled not just with religion and kinship but also 
with colonial ideas about intimacy and embodiment (Stoler 1995, 2002; Bear 2007). Tea plantation production provides a ready example of this. Discourses about the sexed and raced bodies of women plantation workers remain woven into discourses about the taste of tea (Chatterjee 2001; Besky 2014b). The cultivated ability of marginalized yet exoticized women laborers to coax flavor from Indian tea sits in direct relationship to the cultivated ability of male elites to properly consume and judge it (Bourdieu 1984). The proposed digitization of the tea auction, to which I now turn, can thus be usefully characterized as a new permutation on an old project of improvement (cf. Drayton 2000).

\section{AUCTION REFORM AND THE FUTURES OF INDIAN TEA}

In a May 2009 interview with a Tea Board bureaucrat in charge of the rollout of the online auction, the bureaucrat explained: "We need to establish a more robust price discovery mechanism, because at present, the price discovery is not actually the real price discovery." She pulled the thick, spiral-bound consultants' report from the shelf behind her. "It's all in there," she continued. "They say the outcry system is completely inefficient - against basic auction principles. The auction needs to be transparent. They said go for the electronic auction.”

The transition I witnessed in 2009 was not the Tea Board's first attempt to institute an electronic auction. In 2002, the Tea Board had created teauction.com, a voluntary, alternative system to which they had hoped traders would gradually gravitate. Even after years of investments, the online platform failed. In 2004, in the wake of that failure, the Tea Board's hired consultant, A. F. Ferguson, issued a report that described the problems with the outcry system and argued that mandatory, rather than voluntary, digitization would facilitate a move toward futures trading. The freeing of the market in Kolkata required strong government intervention. The report details how the outcry system was not an auction at all in (free-market) economic terms. The outcry auction's very chronicity — with lots coming up one at a time and choreographed by an auction catalog and a list of valuation prices - allowed traders to buy "with market trends" (A. F. Ferguson 2004, 2.4.03; cf. Zaloom 2006). The report pointed out that buyers not only knew other bidders but also that during the auction, buyers knew who the highest bidder was and at what price he was bidding. The tone of the report is one of uncovering the secrets of the trade, which kept outcry transactions gentlemanly and cordial, but which also kept prices low and "worked against auction principles." 
In our interview, conducted soon after the mandated reintroduction of digital auctioning, the Tea Board official explained how this latest incarnation was certain to work. Beginning in 2007, the Tea Board contracted the Indian National Stock Exchange Information Technology (NSE-IT) department to redesign the digital auction. The first attempt, she said, had been run by a private IT company that did not have the correct vision for real price discovery:

One should not drive the proposed auction system on an overwhelming desire to get a consensus, because there are so many different stakeholders. We have the producers [plantations]. Then we have the brokers, or the auctioneers. We have the warehouse keepers. We have the buyers. And after buyers, post-auction, we have a system of traders. And different parties have different conflicting interests. The interest of the sellers [plantations] is completely different from the interest of the buyers. So, there will never be a consensus. . . . The focus on price was never their concern.

Echoing the suggestions of the A. F. Ferguson report, the official repeated that "real prices" were not being "discovered" in the outcry auction system because of this complex network of social relationships. The outcry structure, with buyerbrokers making purchases for any number of international retailers, splitting lots with one another, and sharing tea and cigarettes with seller-brokers working for Indian plantation companies, conspired against the discovery of high prices.

The official was sure that this attempt at digitization, five years after the initial failed attempt, was going to work, even if it had to be unilaterally imposed by the Tea Board:

These buyers . . . they can't accept change . . . and they are unscrupulous. The computerized system will be inherently better because it will be impartial. These buyers all go to lunch with each other, and then come back into the auction room. How can that lead to fair prices? They are far too friendly with each other. [The brokers] say that the auction is so personalized; that it is vibrant, exciting. But it needs to be impersonal. The computer is impartial.

For the Tea Board, rich, vibrant social relations constituted the ultimate obstacle to the realization of price. The express objective of the digital auction was to turn a collective process of storytelling into an individualized one of scenario-enactment. As A. F. Ferguson's (2004, 4.4.04) report noted, the "qualitative factors" that went into auction trading could not be ignored: not everything could be 
done by computer. Brokers had to act on knowledge about the taste and provenance of the tea they traded, but they needed to learn to keep such knowledge tacit. While such knowledge remained vital to the trading infrastructure, it had to be seen as existing prior to rather than emergent within the transactions themselves.

The introduction of computerized trading would cultivate such a shift in price composition in three ways. First, it would alter tea's commensurability. For the digital auction to succeed, tea grades had to become universal standards. A. F. Ferguson's report criticized the wide variation in grades and types of tea as idiosyncratic and opaque, calling for a more streamlined relationship between grades and prices. Brokers would still buy and sell SFTGFOP tea, for example, but one lot of SFTGFOP should be commensurable with all other lots of the same kind. There should be no need to know each lot's story. A discourse of natural price discovery trumped discussions of a tea's terroir, or its seasonal and regional variability.

Second, the introduction of computerized trading would change the temporal orientation of price composition. Whereas price stories were oriented to the collective past experience of teas that had come up for auction before, digital price scenarios would be oriented to individual feelings about tea's future. From millenarian Christianity to disaster management, scenarios are communicative infrastructures and technological practices for tuning individuals to uncertainty. Scenarios are, as Melinda Cooper (2010, 170) describes with respect to weather risk markets, the elaboration of "multiple future worlds, attendant on alternative actions in the present." Scenarios work imaginatively as much as they do technically: they force participants to prepare for events, from crop failures to pandemic emergencies, that have not yet happened but that potentially could (Lakoff 2008; Briggs 2011; Samimian-Darash 2013).

Third, it was clear in my discussions with bureaucrats that if the digital auction worked as planned, buyers would not need to be in the space of Nilhat House at all. Since tacit knowledge was individually held, they could be anywhere. This constituted the ultimate aim: opening up the auction to more participants. In a process similar to those that Zaloom describes during the digital transition of financial spaces in Chicago and London, trade was opened to any individual with a computer through which they could tap into an externalized market. This was one of the express objectives of the scenarios I witnessed in Kolkata - to make trade look and feel like it does for other commodities. 
But how technologies touch down, and how they produce imaginative and communicative states, varies with context. The Tea Board's attack on the auction system as unnatural and corrupt elicited a countercritique from traders directed at the artificiality and opacity of the Tea Board's vision. What was being corrupted, they insisted, was the taste and value of Indian tea. Tea needed their collective skill as storytellers to translate between the material and communicative registers that compose price.

\section{THE DIGITAL TRANSITION}

The first day of the digital CTC auction in May 2009 started like any other. A few minutes before 8:00 a.m., I walked up to the iron gates of Nilhat House and passed dozens of buyers huddled around the tea stalls, cigarettes in one hand, earthen cups in the other. I greeted each of the guards while the brokers and other officials streamed up the marble steps to the auction rooms. But the large CTC auction hall remained almost empty, except for two unfamiliar young men standing where the auctioneers should have been. At each empty seat stood a black laptop. Brokers were milling about outside. "What's going on?" I asked a few buyer-brokers, who were standing in the corner and lighting fresh cigarettes, right at 8:00 a.m., when the auction always punctually started.

"We will go in when we are ready," one responded with a harrumph. "They are trying to replace us with . . . with . . . those things!" he said, motioning back to the auction room with disgust. The lanky, soft-spoken, and well-respected director of the Calcutta Tea Traders had rushed over from his office a few blocks away to usher everyone inside. The brokers tried one last time to convince him that the digital auction was a waste of time. They should just start the analog auction. But the director said that neither he nor they had a choice. This change had been sent down from the Tea Board.

The buyer-brokers went in but would not sit down. Two young technicians from the National Stock Exchange (NSE) IT department tried to reassure the crowd: "It will work this time. . . . We have worked out the kinks." With eye rolls and crossed arms, the sea of middle-aged men sat down.

I sat next to two older buyer-brokers. Without prompting, one of them said: "Years of experience and knowledge, just tsssss!" He blew air through his teeth, making a sound like steam hissing from a kettle, and flipped his hand in disgust toward the open computer in front of him. After the technicians had gone around and ensured that each of the brokers had signed in with his unique password, the auction began, just after 10 a.m. 
Immediately, thirty-six lots came up at once. Screams and hollers came from the audience:

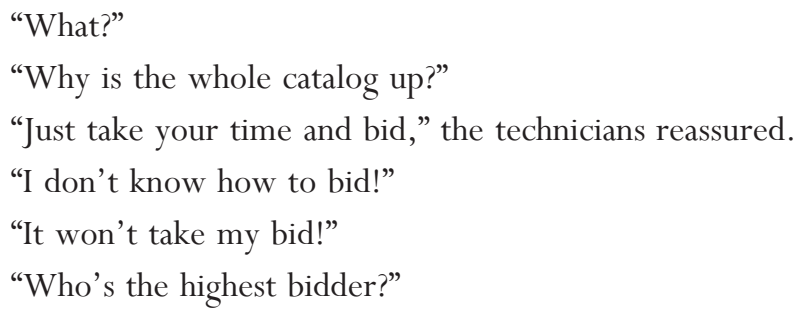

The older buyer-broker I was sitting with was trying to buy tea. He put in a high bid, but didn't get the lot he wanted. He called the technicians over. "It's not me! It's not me!" He pointed to the screen. "It's New Tea Centre [another CTTA-registered firm]. Where did my bid go?"

The other man who he was sitting with shut the hood of his laptop and pulled out a snack bag of bhuja, offering his companion some. "It's like bidding in a vacuum. Nobody knows what is going on and that is the way they want it. This is what they mean by transparency."

The digital auction replaced the linear structure of the auction catalog and the one-lot-at-a-time sequential order with a website that flashed multiple random lots at one time, for which buyers had one minute to bid. This led to outrage in the auction hall, but according to Tea Board officials I interviewed, the randomness had been instituted to prevent buying with market trends. "It has been proven,” one Tea Board official told me, drawing on behavioral economics theory, "that when people don't know what is coming up next, they buy more, and at higher prices."

In the digital scenario, brokers were being asked to take individual responsibility for their bids and, in a very real sense, to bid in a vacuum. The aleatory nature of the bidding process undid the social infrastructure of communicative channels. With no time for open discussion, brokers' knowledge was rendered tacit in a new way.

That new form of tacitness was punctuated by the crunch of bhuja, the imitations of tea kettles, and the spontaneous outbursts of emotion. Later in the proceedings, a roar of laughter came over part of the room. The high bid for a lot of low-grade CTC was currently at 10,000 rupees (about \$225) a kilogram, instead of the 100 rupees at which it was valued. The current high bidder screamed: "I withdraw the bid! I withdraw the bid!" This plea, however, could not be answered, as there was no longer an auctioneer physically mediating the 
proceedings. Despite sitting in his seat at the front of the room, the auctioneer could do nothing except raise or lower the reserve price. The usually suave and commanding man just looked up from his lectern and shrugged.

What upset the brokers at Nilhat House was that digital trading scenarios violated an aesthetic and ethical connection between a style of trading, a style of production, and a style of consumption, as well as the very space of Nilhat House. Unlike futures traders in Chicago and London, who had little material connection to the products they moved, tea brokers knew tea-and tea plantations - on intimate terms (Zaloom 2006, 97). The sensory aspects of soils and waters, as well as of aromas and flavors - were as important as the embodied process of calling out lots, splitting lots, and jockeying for particular grades. Brokers felt that tea's idiosyncrasies (the flushes, regions, and grades that caused daily differentiation and took them a career to master) made it a bad fit for a valuation practice based on the spontaneous and individual, rather than collective and recursive, application of tacit knowledge. Tea's particular sensory qualities created a material barrier between India and the global market to which the digital system was supposed to link the nation. When the Tea Board attempted to replace the open-outcry auction with digital trade, tasters and buyers felt not so much a disembedding (see K. Polanyi 2001) as a change in the relationship between knowledge, thing, and price. Knowledge about tea was no longer arbitrated within the transaction, but outside of it. In a reversal of what Caitlin Zaloom describes, tea traders in Kolkata experienced the digital transition as one from storied, sober, collegial interaction under the open-outcry system to adversarial combat under the computerized one. Such a difference in the social experience of financial technologies illustrates how the communicative infrastructures that preexist digital market transitions create variability in the infrastructures resulting from those transitions.

While the storied price composition of the outcry system depended on a polite rendering of an agreed-upon past (of provenance, origin, and embodied memory), the pricing scenario of the digital auction reoriented traders to an uncertain future: a future in which traders were still dealing with actual tea but faced the risk of buying too much or not enough.

Whereas outcry brokers learned to participate in the crafting of price stories through a slow apprenticeship and a social infrastructure based on gentlemanly camaraderie, the imagined participant in the digital auction was not an apprentice, but a trainee. Just as the digital auction was being revived in 2009, private firms began to offer aspiring young brokers a new product: training in tea tasting and 
valuation. In institutions from the Birla Institute of Management and Futuristic Studies (a subsidiary of the Birla tea company) to Assam Agricultural University, students can now purchase lessons in the secrets of tea tasting, preparing to enter a reformed auction system, based on standardized scenarios, that would welcome a greater number of participants, imagined not as colleagues but as competitors (cf. Elyachar 2012, 88). Whereas particular price stories draw a small community together within a discrete, shared social and ecological space, generalized price scenarios organize large numbers of people over a vast scale. These people need share nothing but a desire either to buy or to sell.

\section{CONCLUSION}

It appears, then, that brokers' collectively honed knowledge has been repackaged as a commodity unto itself. Yet as Julia Elyachar $(2012,90)$ notes - in line with Jane Guyer's (2009) suspicion of facile narratives of commoditizationthe repackaging of knowledge as a fungible commodity is rarely so seamless. While neoliberal theorists have drawn on Michael Polanyi's notion of tacit knowledge in science to argue that rational economic orders must emerge through spontaneous actions, I have shown in this essay how a move to foment a spontaneous relationship between price and knowledge actually requires a great deal of governmental and nongovernmental planning.

Through an account of an attempt to financialize tea in India, I have shown how digital technology puts the theories of behavioral economics into action (MacKenzie 2006; Zaloom 2006). Ideas about the transparency, impartiality, and rationality of digital systems reveal how visions of India's economic future depend on the elimination of cloistered expertise and its replacement by a distributed, democratic knowledge, acquirable through training rather than apprenticeship. This elimination replaces what I have called the collective, embodied story of price with the enactment of standardized, individualized scenarios. This shift appears to allow numbers to speak for themselves, because participation in their production is radically distributed, while the possible actions taken to produce them are radically limited. The shift to scenario-based price discovery links Indian tea-industry reform to broader discussions of the social contexts of technological change in global finance (Zaloom 2006; MacKenzie 2006; Preda 2006; Miyazaki 2013), as well as to other technoscientific changes in the global economy of nature and numbers, from bioterrorism to epidemiology to climate change models (Lakoff 2008; Samimian-Darash 2013; Edwards 2010). Putting models into practice through scenarios is a prerequisite to the implementation of new forms of sur- 
veillance and control in the future, but it is also central to the elaboration of new kinds of market relationships in the present. Price scenarios work to turn environmental commodities like tea-fickle, particular, and shifting like pathogens, air, and water - into potential financial instruments.

To conceive of finance as an anthropological object, then, we must think about the physical dismantling of auction houses as much as about the physical opening up of goldmines or hydraulically fractured shale formations. At an even broader level, attention to the technologies of market opening puts the anthropology of finance into dialogue with ethnographic approaches to modernity and infrastructure, which are already rich in attention to how planning accounts for (or ignores) spontaneity and "leakage" (Anand 2011; see also Appel 2012; Larkin 2013). Leakages, whether they are what literally flows out of pipe crevices or the outbursts of traders who "don't know what's coming up next," are as common in price compositions as in city water systems.

Efforts to reform India's tea industry are ongoing. Obstacles to financialization in the tea sector exist in multiple locations within the colonially derived production infrastructure. Since 2009, tea brokerage in India has become a hybrid system, with digital technologies wedged awkwardly into the old outcry model. The seller-brokers and buyer-brokers still gather in the auction rooms of Nilhat House. The long list of grading and tasting terms continues to confound attempts to commensurate tea grades for rapid digital trading. Still, the push for digitization in the auction continues, not least because online sales have taken off elsewhere during the past five years. A growing number of direct traders, who use the Internet to cultivate buyers in Europe and America, have managed to circumvent the auction. Direct traders are threatening the status of the tea trade as a national institution. The Tea Board is trying to meld the ethic of speed and seamlessness that marks digital trading with the quality assurance offered by the auction. To do so, the Tea Board has marshaled a new kind of expert authority. The savvy, young (but still overwhelmingly upper-middle-class, English-speaking, and male) IT expert has started to replace the wizened, middle-aged taster-broker. The push for digitization is part of a broader attempt to keep tea palatable in India, both politically and socially. Digitization has come along with bold pronouncements about the beginning of the end of the plantation system, with its variable geographies, esoteric factory processing procedures, and archaic labor process. The taste of tea in the broadest sense - its association with refinement but also with enlightened liberal values - is at stake. 
Yet as I have argued in this essay, to understand efforts to financialize fields and factories, we must understand how those efforts resonate with similar moves to transform a more hidden communicative infrastructure of price composition in places like the tasting and auction rooms of Nilhat House. Such an analysis enables the anthropology of finance to join studies of environment and development by critically engaging megaprojects that do not take the form of dams, roads, or other modernist structures.

\begin{abstract}
For more than 150 years, most tea grown on plantations in northeast India has been sold in open-outcry auctions in Kolkata. In this essay, I describe how, in 2009, the Tea Board of India, the government regulator of the tea trade, began to convert auctioning from a face-to-face outcry process to a face-to-computer digital one. The Tea Board hoped that with the implementation of digital technologies, trade would soon revolve around the buying and selling of futures contracts, not individual lots of tea. Despite these efforts, the tea industry has thus far resisted all attempts at financialization. That so prominent a commodity as tea has yet to be financialized provides a unique opportunity to examine the how of financialization - the governmental and technical steps that precede futures and other kinds of derivatives markets. Futures markets rely on a standardized notion of price and of the material things being priced. The story of Indian tea's resistance to financialization shows how such standardization requires not just a disentangling of commodities at the level of productive infrastructure (that is, the separation of individual trader and thing being traded) but also a reworking of the communicative infrastructure of trading. In this essay, I analyze this reworking by examining the effort to reform how tea is priced at auction. Specifically, I describe a transition in tea valuation from socially embedded price stories to standardized price scenarios. [brokerage; bureaucracy; tacit knowledge; economic reform; scenario]
\end{abstract}

\title{
NOTES
}

Acknowledgments Thanks to Dominic Boyer, the Cultural Anthropology editorial collective, and the anonymous reviewers for their helpful feedback on this manuscript. Many other people have also provided comments on it during the past few years, including Nicholas D'Avella and Paige West at a 2012 panel on Enumerating Environments at the annual meetings of the American Anthropological Association, Nikhil Anand and Anuradha Sharma at the 2012 Annual Conference on South Asia, Martha Lampland, Daniel Hirschman, Caroline Schuster, Alex Blanchette, Matthew Hull, and colleagues at Brown University, North Carolina State University, University of Cologne, University of Edinburgh, University of Michigan, and the 2014 biennial meeting of the Society for Cultural Anthropology. Special thanks to Alex Nading for his detailed responses to this article's multiple incarnations. Funding was provided by the Fulbright-Hays Doctoral Dissertation Research Abroad Program, the American Institute of Indian Studies, the Land Tenure Center at the University of Wisconsin-Madison, the Andrew W. Mellon Foundation, the American Council of Learned Societies, and the Michigan Society of Fellows. All errors are my own. 
1. There are seven auction centers in India. In addition to the largest in Kolkata (West Bengal), there are centers in Guwahati (Assam), Jalpaiguri (West Bengal), Siliguri (West Bengal), Cochin (Kerala), Coonoor (Tamil Nadu), and Coimbatore (Tamil Nadu).

2. In Caitlin Zaloom's $(2003,259)$ case, the digital transition forced traders to change how they reacted to the numbers that constituted the market.

3. As William Roseberry (1996) and Paige West (2012) have shown, the neoliberalization of agriculture allows for the creation of specialty markets in which taste - in both of its Bourdieuian senses - is more important than ever.

4. For the sake of clarity I use the term seller-brokers to describe people who taste and auction tea and buyer-brokers to describe people who buy tea at auction. In everyday auction parlance, sellers are actually plantations, buyers are what I call "buyer-brokers," and brokers are what I call "seller-brokers."

5. This tea is not from China, but it is the "Chinese variety" of bush (Camellia sinensis).

\section{REFERENCES}

A.F. Ferguson \& Company

2004 "Study on Primary Marketing of Tea in India-Final Report."

Anand, Nikhil

2011 "Pressure: The PoliTechnics of Water Supply in Mumbai." Cultural Anthropology

Appadurai, Arjun 26, no. 4: 542-64. http://dx.doi.org/10.1111/j.1548-1360.2011.01111.x.

1996 Modernity at Large: Cultural Dimensions of Globalization. Minneapolis: University of Minnesota Press.

Appel, Hannah

2012 "Walls and White Elephants: Oil Extraction, Responsibility, and Infrastructural Violence in Equatorial Guinea.” Ethnography 13, no. 4: 439-65. http:// dx.doi.org/10.1177/1466138111435741.

Arnold, David

2005 “Agriculture and 'Improvement' in Early Colonial India: A Pre-History of Development." Journal of Agrarian Change 5, no. 4: 505-25. http://dx.doi.org/ 10.1111/j.1471-0366.2005.00110.x.

Atkin, Peter

2010 Liquid Materialities: A History of Milk, Science, and the Law. Farnham, U.K.: Ashgate. Ballestero, Andrea

2015 "The Ethics of a Formula: Calculating a Financial-Humanitarian Price for Water.” American Ethnologist 42, no. 2: 262-78. http://dx.doi.org/10.1111/ amet.12129.

Bear, Laura

2007 Lines of the Nation: Indian Railway Workers, Bureaucracy, and the Intimate Historical

Beck, Ulrich Self. New York: Columbia University Press.

1992 Risk Society: Towards a New Modernity. London: Sage.

Besky, Sarah

2014a The Darjeeling Distinction: Labor and Justice on Darjeeling Tea Plantations. Berkeley: University of California Press.

2014b "The Labor of Terroir and the Terroir of Labor: Geographical Indication on Darjeeling Tea Plantations.” Agriculture and Human Values 31, no. 1: 83-96.

Bourdieu, Pierre http://dx.doi.org/10.1007/s10460-013-9452-8.

1984 Distinction: A Social Critique of the Judgment of Taste. Translated by Richard Nice. Briggs, Charles L. London: Routledge.

2011 "Communicating Biosecurity." Medical Anthropology: Cross-Cultural Studies in Health and Illness 30, no. 1: 6-29. http://dx.doi.org/10.1080/01459740. 2010.531066. 
Callon, Michel, ed.

1998 Laws of the Markets. Oxford: Blackwell.

Chatterjee, Piya

2001 A Time for Tea: Women, Labor, and Post/colonial Politics on an Indian Plantation. Durham, N.C.: Duke University Press.

Cohn, Bernard S.

1996 Colonialism and Its Forms of Knowledge: The British in India. Princeton, N.J.: Princeton University Press.

Cooper, Melinda

2010 “Turbulent Worlds: Financial Markets and Environmental Crisis.” Theory, Culture \& Society 27, nos. 2-3: 167-90. http://dx.doi.org/10.1177/ 0263276409358727.

Cronon, William

1992 Nature's Metropolis: Chicago and the Great West. New York: W. W. Norton.

D’Avella, Nicholas

2014 "Ecologies of Investment: Crisis Histories and Brick Futures in Argentina." Cultural Anthropology 29, no. 1: 173-99. http://dx.doi.org/10.14506/ca29.1. 10 .

Drayton, Richard

2000 Nature's Government: Science, Imperial Britain, and the "Improvement" of the World. New Haven, Conn.: Yale University Press.

Edwards, Paul N.

2010 A Vast Machine: Computer Models, Climate Data, and The Politics of Global Warming. Cambridge, Mass.: MIT Press.

Elyachar, Julia

2005 Markets of Dispossession: NGOs, Economic Development, and the State in Cairo. Durham, N.C.: Duke University Press.

2010 "Phatic Labor, Infrastructure, and the Question of Empowerment in Cairo." American Ethnologist 37, no. 3: 452-64. http://dx.doi.org/10.1111/j.15481425.2010.01265.x.

2012 "Before (and After) Neoliberalism: Tacit Knowledge, Secrets of the Trade, and the Public Sector in Egypt.” Cultural Anthropology 27, no. 1: 76-96. http:// dx.doi.org/10.1111/j.1548-1360.2012.01127.x.

Espeland, Wendy Nelson, and Michael Sauder

2007 "Rankings and Reactivity: How Public Measures Recreate Social Worlds." American Journal of Sociology 113, no. 1: 1-40. http://dx.doi.org/10.1086/ 517897.

Espeland, Wendy Nelson, and Mitchell L. Stevens

1998 "Commensuration as a Social Process." Annual Review of Sociology 24: 313-43. http://dx.doi.org/10.1146/annurev.soc.24.1.313.

Fourcade, Marion

2011 "Cents and Sensibility: Economic Valuation and the Nature of 'Nature." American Journal of Sociology 116, no. 6: 1721-77. http://dx.doi.org/10.1086/659640.

Gupta, Akhil

1995 "Blurred Boundaries: The Discourse of Corruption, the Culture of Politics, and the Imagined State.” American Ethnologist 22, no. 2: 365-402. http: / / dx.doi.org/ 10.1525/ae.1995.22.2.02a00090.

Guyer, Jane I.

2009 "Composites, Fictions and Risk: Toward an Ethnography of Price." In Market and Society: The Great Transformation Today, edited by Chris Hann and Keith Hart, 203-20. Cambridge: Cambridge University Press.

2010 “The Eruption of Tradition? On Ordinality and Calculation." Anthropological Theory 10, nos. 1-2: 123-31. http://dx.doi.org/10.1177/1463499610365378.

Ho, Karen

2009 Liquidated: An Ethnography of Wall Street. Durham, N.C.: Duke University Press. 
Hull, Matthew S.

2012 Government of Paper: The Materiality of Bureaucracy in Urban Pakistan. Berkeley: University of California Press.

Janeja, Manpreet K.

2010 Transactions in Taste: The Collaborative Lives of Everyday Bengali Food. New Delhi: Routledge India.

John, Gemma

2011 "Freedom of Information and Transparency in Scotland: Disclosing Persons as Things and Vice Versa." Anthropology Today 27, no. 3: 22-25. http://dx.doi. Lakoff, Andrew org/10.1111/j.1467-8322.2011.00809.x.

2008 “The Generic Biothreat, or, How We Became Unprepared." Cultural Anthropology 23, no. 3: 399-428. http://dx.doi.org/10.1111/j.1548-1360.2008.00013.x.

Larkin, Brian

2013 “The Politics and Poetics of Infrastructure." Annual Review of Anthropology 42: 327-43. http://dx.doi.org/10.1146/annurev-anthro-092412-155522.

LiPuma, Edward, and Benjamin Lee

2004 Financial Derivatives and the Globalization of Risk. Durham, N.C.: Duke University Press.

MacKenzie, Donald

2006 An Engine, Not a Camera: How Financial Models Shape Markets. Cambridge, Mass.: MIT Press.

2009 "Making Things The Same: Gases, Emission Rights and the Politics of Carbon Markets." Accounting, Organizations and Society 34, nos. 3-4: 440-55. http:// dx.doi.org/10.1016/j.aos.2008.02.004.

Marx, Karl

1976 Capital, Volume One. Translated by Ben Fowkes. New York: Penguin. Originally published in 1867 .

Mazzarella, William

2006 "Internet X-Ray: E-Governance, Transparency, and the Politics of Immediation in India.” Public Culture 18, no. 3: 473-505. http://dx.doi.org/10.1215/ 08992363-2006-016.

Merry, Sally Engle

2011 "Measuring the World: Indicators, Human Rights, and Global Governance." Current Anthropology 52, no. S3: S83-95. http://dx.doi.org/10.1086/657241.

Miyazaki, Hirokazu

2013 Arbitraging Japan: Dreams of Capitalism at the End of Finance. Berkeley: University of California Press.

Moodie, Ellen

2010 El Salvador in the Aftermath of Peace: Crime, Uncertainty, and the Transition to Democracy. Philadelphia: University of Pennsylvania Press.

Narayan, Kirin

1989 Storytellers, Saints, and Scoundrels: Folk Narrative in Hindu Religious Teaching. Philadelphia: University of Pennsylvania Press.

Paley, Julia

2001 Marketing Democracy: Power and Social Movements in Post-Dictatorship Chile. Berkeley:

Polanyi, Karl

University of California Press.

2001 The Great Transformation: The Political And Economic Origins of Our Time. Boston:

Polanyi, Michael Beacon Press. Originally published in 1944.

2009 The Tacit Dimension. Chicago: University of Chicago Press. Originally published in 1966. 
Preda, Alex

2006 "Socio-Technical Agency in Financial Markets: The Case of the Stock Ticker." Social Studies of Science 36, no. 5: 753-82. http://dx.doi.org/10.1177/ 0306312706059543.

Priyadershini S.

2012 “A Tea Time Story.” The Hindu, January 28. http://www.thehindu.com/todayspaper/tp-features/tp-metroplus/a-tea-time-story/article2838319.ece.

Richard, Analiese, and Daromir Rudnyckyj

2009 "Economies of Affect." Journal of the Royal Anthropological Institute 15, no. 1: 5777. http://dx.doi.org/10.1111/j.1467-9655.2008.01530.x.

Roseberry, William

1996 "The Rise of Yuppie Coffees and the Reimagination of Class in the United States." American Anthropologist 94, no. 4: 762-75. http://dx.doi.org/10.1525/aa. 1996.98.4.02a00070.

Samimian-Darash, Limor

2013 "Governing Future Potential Biothreats: Toward an Anthropology of Uncertainty.” Current Anthropology 54, no. 1: 1-22. http://dx.doi.org/10.1086/ 669114.

Simmel, Georg

1978 The Philosophy of Money. Translated by Tom Bottomore and David Frisby. New York: Routledge, Kegan, and Paul.

Solomon, Harris

Forthcoming Metabolic Living: Food, Fat, and the Absorption of Illness in India. Durham,

Stoler, Ann Laura N.C.: Duke University Press.

1995 Race and the Education of Desire: Foucault's History of Sexuality and the Colonial Order of Things. Durham, N.C.: Duke University Press.

2002 Carnal Knowledge and Imperial Power: Race and the Intimate in Colonial Rule. Berkeley: University of California Press.

Sunder Rajan, Kaushik

2005 "Subjects of Speculation: Emergent Life Sciences and Market Logics in the United States and India." American Anthropologist 107, no. 1: 19-30. http://dx.doi.org/ 10.1525/aa.2005.107.1.019.

West, Paige

2012 From Modern Production to Imagined Primitive: The Social World of Coffee from Papua Zaloom, Caitlin New Guinea. Durham, N.C.: Duke University Press.

2003 "Ambiguous Numbers: Trading Technologies and Interpretation in Financial Markets.” American Ethnologist 30, no. 2: 258-72. http://dx.doi.org/10.1525/ ae.2003.30.2.258.

2006 Out of The Pits: Traders and Technology from Chicago to London. Chicago: University of Chicago Press. 